\title{
UDC 130.12+316.3
}

\section{M. HOIAN ${ }^{1 *}$}

1 *Vasyl Stefanyk Precarpathian National University (Ivano-Frankivsk, Ukraine), e-mail ivigoian@gmail.com, ORCID 0000-0003-2548-0488

\section{AXIOLOGICAL ASPECTS OF MORAL AND LEGAL DECISION-MAKING}

Purpose. The study seeks to clarify the preconditions for moral and legal decision-making based on the identification of axiological foundations that correlate with the moral perceptions of good and evil and psychological phenomena such as emotions. Theoretical basis of the study is to apply comparative, axiological, systemic methods. This methodological approach allows us to analyze and disclose the essence of the process of moral and legal decision-making on the basis of certain axiological prerequisites and enables to substantiate the connection between the axiological and psychological aspects of taking moral and legal decisions. Originality of the work is to broaden the perceptions of the processes and mechanisms for making moral and legal decisions, which are based on the axiological dimension, in particular on the system of reference individual and social values. The study shows that every necessary moral and legal decision taken by a person is futurologically balanced in the emotional sense, rationally reasoned and morally perceptible in the context of man's beliefs about good and evil, and realized with necessity in the personal system of reference values that determines the style and manner of individual and social behaviour in the context of material and spiritual values and is an axiological foundation for making all types of moral and legal decisions. Conclusions. Moral and legal decision-making is a social process that is connected with such a social essence of a person as rationality, which gives an opportunity to act axiologically. A person makes moral and legal decisions in a complex way, based on the unity of the moral, axiological and psychological aspects of his worldview, which are grounded on the system of reference values.

Keywords: moral and legal decision; axiological aspect of decision making; system of reference values

\section{Introduction}

Human life in society implies a conscious and rational choice, which is conditioned by certain mechanisms. Human choice of behaviour and activity is related to making important decisions and actions based on those decisions. Making a decision has a complex outlook and psychological dimension. Often, people make decisions intuitively, based on their previous experience and immediate emotional experiences at the moment of decision-making. Decisions are also made rationally based on understanding of the decision-making conditions and its possible consequences. Preferably, the conditions under which the decision is made predict its possible consequences, which, in our opinion, are related to values. That is to say, the necessary moral and legal decision-making has an axiological aspect, and we make our primary task to investigate its features within the framework of our scientific study.

\section{Purpose}

The axiological aspects of moral and legal decision-making are often left unaddressed by researchers, or ignored in the context of, for example, neurosciences, which, being interdisciplinary, are still prone to reduce a person's moral behaviour and motivation to biological, biochemical or linguistic phenomena, which are considered objective and natural. Therefore, the main task of our scientific exploration is to study the axiological preconditions on the basis of which a person makes moral and legal decisions about the dimension of a particular action. 
In the study, we focus our attention on identifying the axiological specifics based on which a person makes moral and legal decisions, because these decisions are made in the context of the basic ideological and axiological guidelines, in particular, ideas about good and evil. Therefore, the necessary moral and legal decision has its axiological basis, which, when making a benevolent decision, tends to humanism, altruism and all related values; and when making a malevolent decision, a person is guided primarily by anti-human and selfish principles of conduct and values. A person's predilection for benevolent or malevolent behaviour is in no way determined by genetic or biological laws, since then the latter would exclude human freedom as its essential feature.

In general, the study seeks to clarify the prerequisites for moral and legal decision-making by identifying axiological bases that correlate with moral perceptions of good and evil and psychological phenomena such as emotions.

\section{Statement of basic materials}

The problem of moral and legal decision-making is being developed by researchers from different scientific fields, but in most of the scientific works analyzed by us the researchers only partially draw their attention to the axiological aspects of moral and legal decision-making. Currently, there are a number of interesting and at the same time controversial papers that analyse the various factors of moral decision-making. In particular, the Canadian researcher Paul Thagard (2007) examines the specificity of decision-making due to a conflict of interest based on affective neuroscience, which studies emotional systems in the brain, and he tends to believe that our decisions and judgments often stem from the unconscious interaction of numerous areas of the brain, that encode emotions (p. 379). From the point of view of P. Thagard (2007), the primary thing in the formation of emotions, which in turn influence decision-making, is the unconscious interaction of the various sections of the human brain, which is also biologically conditioned, although rather the unconscious activity and activity of the human brain is not the reason, but a result of the activity of human consciousness and the mental processes that structure the mental sphere. Neurocognitive moral decision-making is explored by American scientist Joshua D. Greene (2003, 2014), who develops ideas of the process of moral judgments based on neurocognitive phenomena and rational human choice of action. At the same time, neurocognitive phenomena cannot at all substantially precede rational choice in time, but are rather simultaneous with it. The German researcher T. Fuchs (2006) draws attention to methodological problems in neuroscience, in particular to the problems of neuroethics, and critically observes that biological reductionism of ethical behaviour provokes discussions about such important for Western culture and society ideas such as free will, freedom and responsibility of individual, its selfhood, while possible nerve correlates of personality based on technical interference cause problems for personal rights to privacy, non-interference and personal inviolability. In general, the neurocognitive effects of brain areas on moral decision-making are, in our view, debatable, since in reality, any decision is made not by the brain and the nervous system, but by a person based on his or her self-consciousness, that is on own ideological and axiological preferences, their awareness and choice of the possible type of behaviour in the system of life values, which are necessarily correlated with the cultural and historical conditions of human life. On the other hand, we should take into account the opinion of S. Vehmas (2011), according to which neurocognitive disorders influence in general the peculiarities of moral perception and the formation of emotions; and the opinion of a number of researchers who, when analysing the peculiarities of moral judgment dur- 
ing dementia (i.e., cognitive impairment resulting from organic brain damage), link the quality of moral judgment to certain areas of the brain (Baez et al., 2016). However, in making a moral decision the fundamental part is not one or another part of the brain, not the quantity and quality of biochemical processes or the presence of hormones that induce emotions, but the system of worldview professed by man and the system of those values that underlie the worldview.

The studies we have analysed above in the field of neurocognitive and neuroethics are rather a statement of individual cases and individual facts of the dependence of moral judgment on certain areas of the brain. Such dependence of the moral on the biological is observed at the level of patterns rather due to pathologies, traumas and diseases that are unintentionally suffered by the person, and therefore one should not take the position of biological reductionism in relation to the peculiarities of the formation of moral and legal behaviour as a fundamental methodological basis for the analysis of the essence of moral and legal decisions. The moral rather depends not on biological or genetic patterns, but on rational, axiological and ideological factors that one deliberately chooses.

In our research we will apply comparative, axiological, systemic methods. This methodological approach allows us to analyse and disclose the essence of the process of moral and legal decision-making on the basis of certain axiological prerequisites and enables to substantiate the connection between the axiological and psychological aspects of taking moral and legal decisions. Identifying such a connection is a difficult task, since one should also take into account the influence of biological factors on the process of moral and legal decision-making, although such influence is usually debatable.

Human being is the one who, having rationality as a species trait and, as a result, freedom of choice as a social trait, is in the process of constant moral and legal choice. This choice is made virtually daily in certain axiological "coordinates", on the basis of correlation and comparison of predetermined moral and legal social norms and the specific life situation in which a person finds himself.

It is this specificity of the cultural-historical situation, the specificity of the human life world that creates a collision between the moral and legal individual consciousness of the individual and the generally accepted social rules, laws and norms. The solution to such a collision between the individual and the social is to make a moral and legal decision, which becomes the motivation of human action in specific living conditions. It is natural that a person's moral and legal decision-making is an extremely complex process in which the various spheres of individual consciousness are systematically involved, since all decisions are made by the person within its limits.

All decisions, without exception, that a person makes in the course of his social activity and behaviour, in our opinion, have three main aspects - axiological, moral and psychological. It is possible to speak of course that biological or physiological, biochemical processes are involved in making certain decisions. For example, some researchers in the field of neurocognitive studies believe that neurocognitive systems in the form of certain areas of the brain, such as ventrolateral prefrontal cortex, amygdala and medial orbital frontal cortex, are involved in the process of ethical decision-making (J. Blair, Marsh, Finger, K. S. Blair, \& Luo, 2006). Such ideas are usually interesting because they are attempts to explain a person's behaviour from an objective point of view, excluding subjective experiences, stereotypes and prejudices, which are predominantly relational. But, in our opinion, the physical-chemical and neurobiological activity of these or other parts of the brain is not the cause, but the consequence of the activation of rational-axiological, 
psychological and moral processes in the human mind, and not vice versa. That is, moral judgments are not automatic (Miller, 2008), because otherwise one must interpret man as a certain mechanism, as a man-machine, as a thinking matter, or as considered by J. Lamettrie (1983), as a matter which only responds to the activation of areas of the brain and nervous system, and the latter depends entirely on the conditions of the natural and social environment.

In our opinion, a decision about action and behaviour is made not by the brain or its specific area, not by the nervous system, but by a man, as a social phenomenon based on self-awareness, worldview and its elements. The brain is only the material basis of consciousness, and therefore it is not directly related to the decision-making process, because decision-making is only a social process, one that is connected with the rational and social, not biological, essence of man. The very conditions of the decision-making process indicate that these are first and foremost social conditions, which imply a rational awareness of the existence of other people, who are also empowered with similar rights and obligations.

Outside of society and its moral and legal norms, decision making is absurd, since in such a case there will be no external criterion for decision making in the form of another person's consciousness. It is the moral and legal norms, which are also in the consciousness of another person, create the conditions and criteria for a person to make a decision, because the decision involves a conscious choice by a person of a certain behaviour, which, in turn, aims at the priority social values that are the purpose of activity. That is, a person's decision has an axiological basis rather than a biological or mechanical combination of stimuli affecting human behaviour. In this context, for example, Christopher L. Suhler and Patricia Churchland (2011) criticize Jonathan Haidt's theory of morality arguing that we come to moral decisions through intuitive processes as the grounds for morality are innate, in particular emotional, because everything is resolved by emotions, and then the mind "catches up" with them. Here we should rather agree with V. Budz's (2017) reasoning that emotions are inherently rational, because in order for an emotion to influence a person's action it must be rationally understood, and therefore a person cannot a priori, innately or intuitively, make moral and legal decisions, because they are inherently axiological, that is, based on the rational choice of a person of certain behaviour. Even if emotions are important in the decision-making process, such as those that are related to empathy, these emotions are still thought of primarily in the rational realm. Therefore, moral or legal choices are not emotional but rather rational. In turn, on the basis of rationality, any choice is transformed into an axiological choice, because a person always chooses a style and a way of behaving in the context of material and spiritual values, which are fundamental axiological prerequisites for making different types of decisions (T. Gurzhii, A. Gurzhii, \& Seliukov, 2018). In our opinion, such a fundamental axiological prerequisite, on the basis of which a decision is made, is a system of reference values, which in a particular life case can be modified depending on its material and spiritual component. In this aspect, for example, V. Khmil and T. Khmil consider that

...the basis of human society is a substantive form of morality, which is

a manifestation of human freedom in the choice of its own value sys-

tem, which endows the existence with human-dimensional and spiritu- 
ally affirming meanings that pierce the way through historical types of states and societies. (V. Khmil, \& T. Khmil, 2015, p. 7)

If moral and legal decisions were made mainly on the basis of certain a priori or innate emotional structures in the human subconscious, then the idea of morality and law as a free choice of human life would be impossible. That is, the moral and legal activity of a person in such a case would be subject to fatalism, and therefore a person would not be liable for his own actions, since he would not have free will because he would have innate forms of decision-making. In this aspect, indeed,

Worldview and its informational-axiological support directly influence the way of human activity. It influences the formation of values and social feelings in the process of socialization and education of man. A person is educated and socialized in the worldview-information dimensions, and the outlook forms in it certain value priorities for activity and behaviour. (Budz, \& Goyan, 2015, p. 35)

That is why all the everyday moral and legal decisions of a person are individual, personal, unique, because they are made within the unique individual worldview and its value preferences, because otherwise all decisions of people who would be driven only by dominant external factors would be the same-type.

In fact, in our view, each person, having free will, which is not conditioned by innate or transcendental stimuli, possesses moral and legal autonomy on the basis of moral and legal consciousness. The latter also point to the value-normative social conditionality of the decision and to the axiological autonomy of the individual, because the individual is able to make decisions by himself (even if they are erroneous) and to form a system of individual reference values and priorities that often do not coincide with the group and wider social environment, which testifies to the individual style of moral and legal behaviour, regardless of the same external conditions or stimuli of the natural and social environment. Here you can rather agree with the idea that

Certain values and norms are acquired by a person in any case, regardless

of his or her will and desire. It occurs naturally and is necessary already

in the process of primary socialization, under the influence of the envi-

ronment that a person inherits, and which encourages him for some ac-

tions and punishes for others. (Bgazhnokov, 2010, p. 71) 
Than with those considerations that human behaviour and decision-making is guided by biological stimuli (as seen in Freudism and behaviourism), or with the view that a person has an innate emotional environment from which to make moral and legal decisions.

Biological phenomena can preferably be only an incentive to make a decision, not even a motive, because motives, as well as decisions about action, are socio-psychological phenomena. If we take the view that the physicochemical and neurobiological activity of certain areas of the brain and the nervous system as a whole are the cause of moral decisions (Blair et al., 2006; Greene, 2014), such ideas, in our opinion, generally destroy the possibility of ethics, morality and all other social processes in the context of freedom of choice and responsibility. In this case, all decisions made are automatic, mechanical, predetermined by biochemical processes, and therefore can occur only in the context of fatalism, and not by free and responsible choice of personality by certain axiological preferences. That is, according to neurocognitive studies, ethical reactions can be triggered artificially and, accordingly, automatically through effects on certain brain areas and through mechanical stimuli (Blair et al., 2006, p. 24; Lott, 2016, p. 256). It is possible to conclude that if certain chemicals are injected into a person artificially, then he will begin to act more morally, that is, morality then gets purely technical capabilities for life. But such ideas are rather close to behaviourism, according to which a person acts only on the principle of "stimulus - reaction", and in the moral dimension, the person is then inclined to act in the context of fatalism and voluntarism.

Reducing the formation of moral and legal decisions only to external stimuli and response to them is impractical, since a person making a decision acts more strategically, anticipating future events, has emotional futurological expectations and experiences that can go beyond immediate physical stimuli for several years, or even decades. In our opinion, only temporary emotions can be artificially influenced, but it is unlikely that inventing such chemicals or creating an artificial environment for humans would be able to sustain social emotions for a longer time, if that was real then it would be possible even at birth to make "injection" of responsibility, solidarity, trust, patriotism, courage, etc. to a person. But these are just fantastic ideas that can never become reality, because in fact higher types of emotions are brought up and in no way can be artificially stimulated, even with the help of chemicals.

In addition, if these emotions are stimulated chemically, then will a person make a moral and legal, and as a whole, axiological choice? As a rule, the choice is made by the person according to living conditions, to the life safety conditions, because the person is a mortal being. If chemically stimulated in a person, for example, emotions of courage under dangerous conditions for life, then the person will not survive in such a situation. That is, if you artificially suppress in a person, for example, the emotion of fear, then he will not be able to make safe decisions on his own, will not be able to act deliberately, choosing, based on the fear of punishment, certain moral and legal actions. In this aspect, some emotions, such as fear, are crucial for decision making.

In our opinion, people make certain decisions not irrationally under the influence of diverse natural and social stimuli or innate emotions, but consciously on the basis of rethinking and transforming these objective or irrational stimuli in axiological, moral and psychological aspects (Bazaluk, \& Kharchenko, 2018). Of course, when making one decision or another, a different sequence and hierarchy of axiological, moral and psychological aspects may be formed, or a person may, for example, be guided by only one of these aspects. However, we believe that these three aspects of decision-making are mutually correlated, because by the logic of things, for example, the moral aspect should be directly linked to the axiological and psychological ones and 
integrated into the person's worldview structure. Therefore, a person makes a decision about moral / immoral or legal / illegal (or any other) action in a holistic manner, based on the unity of moral, axiological and psychological aspects of his worldview.

No human decisions can be classified as irrational, innate, spontaneous, automatic, reflexive, or mechanical if they are truly moral or legal decisions. The very etymology of the concept of "decision" indicates that a person making a decision ponders, weighs, compares, ultimately chooses the most favourable, optimal, most expedient (at least at the time of decision-making) way of action from several possible or probable alternatives, and then makes decisions, i.e. performs deliberate (rational) selective actions, using primarily mental activity rather than the activity of his brain and nervous system. The latter are only the biological basis of the functioning of consciousness and mind, which develop in the social aspect.

If a person did not live with a need for community; or if he is in the first stages of his socialization as a child; or if he has physical brain injuries that damage certain areas of the brain; or if he has certain physical and mental pathologies; or if he is under the influence of physical pain, psychotropic substances, then it is likely that in such an emergency the role of the brain and nervous system in decision-making is dominant, because the human body will adapt to survive. But would these actions be classified as moral and legal if the person is in such situations?

Any decisions are always conscious and rational, but may be moral/immoral, legal/illegal, benevolent/malevolent, ill-considered/well-considered, successful/unsuccessful, fast/slow, false/correct, winning/losing, effective/ineffective, favourable/unfavourable, strategic/tactical, but will never be irrational, since any moral or legal decision will necessarily have an axiological dimension to the choice of one or other values as the purpose of the activity, and the choice is a rational component of any decision.

In particular, decisions are made by a person in the moral aspect, based on believes of good and evil within the world picture; in the axiological aspect - based on the system of reference values and their hierarchy, which man uses as a guide in his life, and which also belong to the worldview; in the psychological aspect - guided by the dominant emotions and feelings that a person experiences, thinking, in turn, about the motives and consequences of making such decisions in the future, in accordance with the worldview.

In this aspect, moral perceptions of good and evil, which are to some extent conservative, are correlated with the axiological parameters of decision-making, that is, the person's system of reference values, and with the psychological parameters of decision-making at the level of futuristic emotions aspect.

It should also be borne in mind that moral ideas, reference values and emotions, as decisionmaking factors, do not exist outside the person, because the person is their bearer and unites them in their own worldview and accordingly, taking this individual worldview, makes a certain decision. Here you can agree with the idea that "the centre, the brightest and fullest expression of culture is the person itself, not norms, values or artefacts... Therefore, it is not values and norms per se, but people, specific persons, that create or set certain coordinates and parameters of socio-cultural space" (Bgazhnokov, 2010, p. 87).

Most of the values of morals and rights that people are guided by in their decision-making are spiritual, such as freedom, dignity, tolerance, justice, order, responsibility. The latter, in our view, can in most cases be considered a system of reference values of the individual and society, since most people and most societies focus on these values. But at the same time, moral obligations and axiological preferences, as well as moral and legal decisions made by a person, in our 
opinion, are formed not in relation to norms, values, rules, duties, rights, but rather in relation to other people who have a more real dimension than values, although values are a condition of giving significance to other people in moral and legal decisions. In this aspect the values are certain transcendental conditions for giving importance and significance to people. That is, for decisionmaking other people are more important than the values themselves. When making a decision, a person does not think about what the rules, values, obligations, rights will say about his decision, but rather thinks about how other people respond to the decision. That is why, when making a decision, a person tries to take into account the future emotional and behavioural response of the near and far social environment, because it is this social environment, not norms and values, that takes sanctions when needed regarding human decisions.

Every person experiences a decision-making process at the emotional level when making decisions. Man makes his choice of behaviour, feeling a complex system of emotions and feelings, which often arise as possible personal and social phobias for the results and consequences of decision-making, but again these phobias, emotions and feelings are felt by man in relation to other people. In most cases, the person is guided by the experience of possible suffering or pleasure that he will hypothetically receive in the future in a social environment. In making this or that decision, a person rationally weighs all the possible negative and positive consequences and makes the decision mainly in the case if the possible positive consequences in the future picture of the world dominate. In other words, the person models the emotional futuristic expectations of the consequences of the decision made in the context of the social environment on the basis of the worldview.

\section{Originality}

In the study, we analysed the processes and mechanisms for making moral and legal decisions, which are based on the axiological dimension, in particular on the system of reference individual and social values. The study proves that every necessary moral and legal decision taken by a person is futurologically balanced in the emotional sense, rationally reasoned and morally perceptible in the context of man's beliefs about good and evil, and realized with necessity in the personal system of reference values that determines the style and manner of individual and social behaviour in the context of material and spiritual values and is an axiological foundation for making all types of moral and legal decisions.

\section{Conclusions}

When making a decision, a person thinks futuristically and in most cases is spontaneously guided by a utilitarian approach that involves elimination of suffering and achieving of pleasure, benefit and happiness due to the decision. It is not excluded that a person may also be guided by altruistic motives in making a decision, but they also have a futurological dimension and are developed in the mind as an assessment of the possible consequences of the decision. That is, a person always predicts and evaluates the possible consequences of his decisions and future actions, and therefore, such futuristic projections and assessments (and in general emotional futurological expectations) are an essential element of decision-making, because one sees himself in the future picture of the social world, in which he is predominantly seeks to avoid physical and mental suffering and moral and legal sanctions from the social environment. In other words, the necessary decision made is futurologically balanced in the emotional sense, rationally rea- 
soned and morally perceptible in the context of man's beliefs about good and evil and realized with necessity in the personal system of reference values that dominate in a certain mentality.

It is neither the brain, nor the nervous system, that makes the decision, but the person as a social phenomenon, and therefore decision-making is only a social process that is connected with the rational and social essence of the person, not with the biological one. In the social aspect, a person makes moral and legal decisions in a complex way, holistically, based on the unity of the moral, axiological and psychological aspects of his worldview, which are grounded on the system of reference values.

The system of referential material and spiritual values, which are necessarily axiological prerequisites for making individual and public moral and legal decisions, can include such fundamental values as life, property, security, welfare, freedom, dignity, tolerance, justice, order, responsibility, patriotism, solidarity, and therefore should be developed in the process of socialization and education in order to establish harmonious social relations.

\section{REFERENCES}

Baez, S., Kanske, P., Matallana, D., Montañes, P., Reyes, P., Slachevsky, A. ... Ibanez, A. (2016). Integration of Intention and Outcome for Moral Judgment in Frontotemporal Dementia: Brain Structural Signatures. Neurodegenerative Diseases, 16, 206-217. doi: https://doi.org/10.1159/000441918 (in English)

Bazaluk, O., \& Kharchenko, L. (2018). The Philosophy of the Cosmos as the New Universal Philosophical Teaching about Being. Philosophy and Cosmology, 21, 6-13. https://doi.org/10.29202/phil-cosm/21/1 (in English)

Bgazhnokov, B. (2010). Antropologiya morali. Nalchik: Izdatelskiy otdel KBIGI. (in Russian)

Blair, J., Marsh, A. A., Finger, E., Blair, K. S., \& Luo, J. (2006). Neuro-cognitive systems involved in morality. Philosophical Explorations, 9(1), 13-27. doi: https://doi.org/10.1080/13869790500492359 (in English)

Budz, V. (2017). Self-Organization of a Man and of Intersubjective Communications as Synergical Autopoiesis of Human Anthropology. In Self-Organisation of Public Reality in the Context of its Anthropological Principles and Axilogical Factors: In 5 vol.: Monograph (Vol. 2). Ivano-Frankivsk: Vasyl Stefanyk Precarpathian National University. (in Ukrainian)

Budz, V., \& Goyan, I. (2015). Informationally-acsiological factors of national and patriotic education of a person and citizen. Socialnoe vospitaniye, 2, 31-41. (in Russian)

Fuchs, T. (2006). Ethical issues in neuroscience. Current Opinion in Psychiatry, 19(6), 600-607. doi: https://doi.org/10.1097/01.yco.0000245752.75879.26 (in English)

Greene, J. (2003). From neural "is" to moral "ought": What are the moral implications of neuroscientific moral psychology? Nature Reviews Neuroscience, 4, 846-850 doi: https://doi.org/10.1038/nrn1224 (in English)

Greene, J. D. (2014). Beyond Point-and-Shoot Morality: Why Cognitive (Neuro)Science Matters for Ethics. Ethics, 124(4), 695-726. doi: https://doi.org/10.1086/675875 (in English)

Gurzhii, T., Gurzhii, A., \& Seliukov, V. (2018). Public Administration of Personal Data Protection in Modern Ukraine. Politické vedy, 21(2), 138-158. doi: https://doi.org/10.24040/politickevedy.2018.21.2.138-158 (in English)

Khmil, V. V., \& Khmil, T. V. (2015). Anthropological aspect of the Nature of the state. Anthropological Measurements of Philosophical Research, 7, 7-15. doi: https://doi.org/10.15802/ampr2015/43374 (in Ukrainian)

Lamettrie, J. (1983). Man-machine. In V. M. Boguslavskiy (Ed.), E. A. Grossman \& V. Levitskiy, Trans. from French, Sochineniya (2nd ed.). (pp. 169-226). Moscow: Mysl. (in Russian)

Lott, M. (2016). Moral Implications from Cognitive (Neuro)Science? No Clear Route. Ethics, 127(1), 241-256. doi: https://doi.org/10.1086/687337 (in English)

Miller, G. (2008). The Roots of Morality. Science, 320(5877), 734-737. doi: https://doi.org/10.1126/science.320.5877.734 (in English)

Suhler, C. L., \& Churchland, P. (2011). Can Innate, Modular "Foundations" Explain Morality? Challenges for Haidt's Moral Foundations Theory. Journal of Cognitive Neuroscience, 23(9), 2103-2116. doi: https://doi.org/10.1162/jocn.2011.21637 (in English) 
Thagard, P. (2007). The Moral Psychology of Conflicts of Interest: Insights from Affective Neuroscience. Journal of Applied Philosophy, 24(4), 367-380. doi: https://doi.org/10.1111/j.1468-5930.2007.00382.x (in English)

Vehmas, S. (2011). Disability and Moral Responsibility. Trames, 15(2), 156-167. doi: https://doi.org/10.3176/tr.2011.2.04 (in English)

\section{LIST OF REFERENCE LINKS}

Baez, S. Integration of Intention and Outcome for Moral Judgment in Frontotemporal Dementia: Brain Structural Signatures / S. Baez, P. Kanske, D. Matallana, P. Montañes, P. Reyes, A. Slachevsky, C. Matus, N. S. Vigliecca, T. Torralva, F. Manes, A. Ibanez // Neurodegenerative Diseases. - 2016. - Vol. 16. P. 206-217. doi: https://doi.org/10.1159/000441918

Bazaluk, O. The Philosophy of the Cosmos as the New Universal Philosophical Teaching about Being / O. Bazaluk, L. Kharchenko // Philosophy and Cosmology. - 2018. - Vol. 21. - P. 6-13. doi: https://doi.org/ 10.29202/phil-cosm/21/1

Бгажноков, Б. Х. Антропология морали / Б. Х. Бгажноков. - Нальчик : Изд. отд. КБИГИ, 2010. - 128 с.

Blair, J. Neuro-cognitive systems involved in morality / J. Blair, A. A. Marsh, E. Finger, K. S. Blair, J. Luo // Philosophical Explorations. - 2006. - Vol. 9, Iss. 1. - P. 13-27. doi: https://doi.org/ $10.1080 / 13869790500492359$

Будз, В. Самоорганізація суспільної дійсності в контексті ії антропологічних засад та аксіологічних чинників : у 5 т. : монографія / В. Будз. - Івано-Франківськ : Прикарпат. нац. ун-т ім. В. Стефаника. - Т. 2 : Самоорганізація людини та інтерсуб’єктивних комунікацій як синергійний автопоезис людської антропології. - 2017. -459 с.

Будз, В. П. Информационно-аксиологические факторы национального и патриотического воспитания человека и гражданина / В. П. Будз, И. Н. Гоян // Социальное воспитание. - 2015. - № 2. - С. 31-41.

Fuchs, T. Ethical issues in neuroscience / T. Fuchs // Current Opinion in Psychiatry. - 2006. - Vol. 19, Iss. 6. P. 600-607. doi: https://doi.org/10.1097/01.yco.0000245752.75879.26

Greene, J. From neural "is" to moral "ought": what are the moral implications of neuroscientific moral psychology? / J. Greene // Nature Reviews Neuroscience. - 2003. - Vol. 4. - P. 846-850. doi: https://doi.org/ $10.1038 / \mathrm{nrn} 1224$

Greene, J. D. Beyond Point-and-Shoot Morality: Why Cognitive (Neuro)Science Matters for Ethics / J. D. Greene // Ethics. - 2014. - Vol. 124, Iss. 4. - P. 695-726. doi: https://doi.org/10.1086/675875

Gurzhii, T. Public Administration of Personal Data Protection in Modern Ukraine / T. Gurzhii, A. Gurzhii, V. Seliukov // Politické vedy. - 2018. - Vol. 21, Iss. 2. - P. 138-158. doi: https://doi.org/ 10.24040/politickevedy.2018.21.2.138-158

Хміль, В. В. Антропологічна компонента природи держави / В. В. Хміль, Т. В. Хміль // Антропологічні виміри філософських досліджень. - 2015. - Вип. 7. - С. 7-15. doi: https://doi.org/ 10.15802/ampr2015/43374

Ламетри, Ж. О. Человек-машина / Ж. Ламетри // Сочинения / Ж. О. Ламетри ; пер. с фр. Э. А. Гроссман, В. Левицкого ; общ. ред., предисл. и прим. В. М. Богуславского. - 2-е изд. - Москва, 1983. C. $169-226$.

Lott, M. Moral Implications from Cognitive (Neuro)Science? No Clear Route / M. Lott // Ethics. - 2016. Vol. 127, Iss. 1. - P. 241-256. doi: https://doi.org/10.1086/687337

Miller, G. The Roots of Morality / G. Miller // Science. - 2008. - Vol. 320, Iss. 5877. - P. 734-737. doi: https://doi.org/10.1126/science.320.5877.734

Suhler, C. L. Can Innate, Modular "Foundations" Explain Morality? Challenges for Haidt’s Moral Foundations Theory / C. L. Suhler, P. Churchland // Journal of Cognitive Neuroscience. - 2011. - Vol. 23, Iss. 9. P. 2103-2116. doi: https://doi.org/10.1162/jocn.2011.21637

Thagard, P. The Moral Psychology of Conflicts of Interest: Insights from Affective Neuroscience / P. Thagard // Journal of Applied Philosophy. - 2007. -Vol. 24, Iss. 4. - P. 367-380. doi: https://doi.org/10.1111/j.14685930.2007.00382.x

Vehmas, S. Disability and Moral Responsibility / S. Vehmas // Trames. - 2011. - Vol. 15, Iss. 2. - P. 156-167. doi: https://doi.org/10.3176/tr.2011.2.04 


\section{I. М. ГОЯН ${ }^{1 *}$}

${ }^{1 *}$ Прикарпатський національний університет імені Василя Стефаника (Івано-Франківськ, Україна), ел. пошта ivigoian@gmail.com, ORCID 0000-0003-2548-0488

\section{АКСІОЛОГІЧНІ АСПЕКТИ ПРИЙНЯТТЯ МОРАЛЬНИХ І ПРАВОВИХ РІШЕНЬ}

Мета. Дослідження спрямоване на з'ясування передумов прийняття моральних і правових рішень на основі виявлення аксіологічних основ, які корелюються з моральними уявленнями про добро і зло та такими психологічними явищами як емоції. Теоретичний базис. Дослідження полягає у застосуванні компаративного, аксіологічного, системного методів. Зазначений методологічний підхід дозволяє аналізувати та розкрити сутність процесу прийняття моральних і правових рішень на основі певних аксіологічних передумов та дає можливість обгрунтувати зв'язок між аксіологічними та психологічними аспектами прийняття моральних і правових рішень. Наукова новизна полягає у розширенні уявлень про процеси та механізми прийняття моральних і правових рішень, що грунтуються на аксіологічному вимірі, зокрема на системі референтних індивідуальних і суспільних цінностей. У дослідженні доводиться, що кожне прийняте людиною моральне і правове рішення 3 необхідністю є футурологічно виваженим в емоційному сенсі, раціонально обміркованим та морально сприйнятливим у контексті уявлень людини про добро і зло, та з необхідністю здійсненим у системі референтних цінностей особистості, яка визначає стиль $\mathrm{i}$ спосіб індивідуальної та суспільної поведінки у контексті матеріальних і духовних цінностей та $\epsilon$ аксіологічним фундаментом для прийняття всіх типів моральних і правових рішень. Висновки. Прийняття моральних і правових рішень - це соціальний процес, який пов'язаний із такою соціальною сутністю людини як раціональність, що дає можливість діяти аксіологічно. Людина приймає моральні й правові рішення комплексно, виходячи з єдності морального, аксіологічного і психологічного аспектів свого світогляду, які грунтуються на системі референтних цінностей.

Ключові слова: моральне і правове рішення; аксіологічний аспект прийняття рішення; система референтних цінностей

\section{И. Н. ГОЯН ${ }^{1 *}$}

${ }^{1 *}$ Прикарпатский национальный университет имени Василия Стефаныка (Ивано-Франковск, Украина), эл. почта
ivigoian@gmail.com, ORCID 0000-0003-2548-0488

\section{АКСИОЛОГИЧЕСКИЕ АСПЕКТЫ ПРИНЯТИЯ МОРАЛЬНЫХ И ПРАВОВЫХ РЕШЕНИЙ}

Цель. Исследование направлено на выяснение предпосылок принятия моральных и правовых решений на основе выявления аксиологических оснований, которые коррелируют с моральными представлениями о добре и зле и такими психологическими явлениями как эмоции. Теоретический базис. Исследование заключается в применении компаративного, аксиологического, системной методов. Отмеченный методологический подход позволяет анализировать и раскрыть сущность процесса принятия моральных и правовых решений на основе определенных аксиологических предпосылок и дает возможность обосновать связь между аксиологическими и психологическими аспектами принятия моральных и правовых решений. Научная новизна. В работе проанализированы представления о процессах и механизмах принятия моральных и правовых решений, которые основываются на аксиологическом измерении, в частности на системе референтных индивидуальных и общественных ценностей. В исследовании доказывается, что каждое принятое человеком моральное и правовое решение с необходимостью является футурологически взвешенным в эмоциональном смысле, рационально обдуманным и морально восприимчивым в контексте представлений человека о добре и зле, и с необходимостью осуществленным в системе референтных ценностей личности, которая определяет стиль и способ индивидуального и общественного поведения в контексте материальных и духовных ценностей и является аксиологическим фундаментом для принятия всех типов мо- 
ральных и правовых решений. Выводы. Принятие моральных и правовых решений - это социальный процесс, который связан с такой социальной сущностью человека как рациональность, дающая возможность действовать аксиологически. Человек принимает моральные и правовые решения комплексно, исходя из единства аксиологического и психологического аспектов своего мировоззрения, которые основываются на системе референтных ценностей.

Ключевые слова: моральное и правовое решение; аксиологический аспект принятия решения; система референтных ценностей

Received: 29.03.2018

Accepted: 18.11.2019 